\title{
Fishery of the Goliath grouper, Epinephelus itajara (Teleostei: Epinephelidae) based on local ecological knowledge and fishery records in Yucatan, Mexico
}

\author{
Alfonso Aguilar-Perera ${ }^{1}$, Carlos González-Salas ${ }^{1}$, Armin Tuz-Sulub $^{2}$ \& \\ Harold Villegas-Hernández ${ }^{1}$ \\ 1. Departamento de Biología Marina, Universidad Autónoma de Yucatán, Km. 15.5, carretera Mérida-Xmatkuil, A.P. \\ 4-116 Itzimná, C.P. 97100, Mérida, Yucatán, México; alfonso.aguilar@uady.mx \\ 2. Centro de Investigación y Estudios Avanzados, Unidad Mérida, Mérida, Yucatán, México.
}

Received 20-XI-2008. C Corrected 02-II-2009. Accepted 02-III-2009.

\begin{abstract}
The Goliath grouper, Epinephelus itajara, a large-bodied $(\sim 2.5 \mathrm{~m} \mathrm{TL},>400 \mathrm{~kg})$ and critically endangered fish (Epinephelidae), is highly vulnerable to overfishing. Although protected from fishing in many countries, its exploitation in Mexico is unregulated; a situation that puts its populations at risk. Fishery records of E. itajara are scarce, which prevents determination of its fishery status. This work aimed to elucidate the $E$. itajara fishery in the northern Yucatan Peninsula by 1) analyzing available catch records and 2) interviewing veteran fishermen (local ecological knowledge) from two traditional landing sites: Dzilam de Bravo and Puerto Progreso. Historic fishery records from two fishing cooperatives were analyzed in order to elucidate the current situation and offer viable alternatives for conservation and management. Catches have decreased severely. Local knowledge obtained from fishermen represented a very important source of information for reconstructing the fisheries history of this species. Conservation measures that incorporate regional and international regulations on critically endangered fish species are suggested. Rev. Biol. Trop. 57 (3): 557-566. Epub 2009 September 30.
\end{abstract}

Key words: reef fish, Goliath grouper, fishery, conservation, Yucatan.

The Goliath grouper, Epinephelus itajara (Teleostei: Epinephelidae), is the largest grouper in the western Atlantic, reaching 400 $\mathrm{kg}$ and $2.5 \mathrm{~m}$ in total length (Bullock et al. 1992, Heemstra \& Randall 1993, Sadovy \& Eklund 1999). This grouper (formerly called jewfish), which ranges throughout the west coast of Africa to the west coast of Central America (including the Caribbean), and from Brazil to the United States, is currently recognized by IUCN as critically endangered (Chan Tak-Chuen \& Padovani Ferreira 2006). As with many groupers, E. itajara is considered extremely vulnerable to fishing due to its life history traits (e.g. slow growth, strong site fidelity, late sexual maturity and formation of spawning aggregations) (Bullock et al. 1992, Sadovy \& Eklund 1999).
In the United States (Atlantic and Gulf of Mexico), E. itajara is severely exploited (Sadovy \& Eklund 1999), although its population and fishery status are actually unknown and difficult to assess (Porch \& Eklund 2004). Fishery regulations for the US Gulf of Mexico in 1989 considered capture size limits up to 1 $270 \mathrm{~mm}$. Fishing of this species has been prohibited since 1990 (Sadovy \& Eklund 1999), and the Caribbean Fisheries Management Council prohibited its capture throughout the US Caribbean in 1993.

In southeastern Mexico, (off the Gulf of Mexico and Caribbean) there is not a diversified fishery regulation for groupers at the level of species. In this region, most of the concern is directed to the management of just one species, the Red grouper, Epinephelus 
morio (SAGARPA 2004). Relatively nothing is known about the biological characteristics, locations, and reproductive seasons of $E$. itajara in Mexican waters. Consequently, knowledge of its biological and fishery components, which is necessary for providing either conservation or management strategies, is practically nonexistent. In the eastern Yucatan Peninsula (Quintana Roo, Mexican Caribbean), fishers suggest that $E$. itajara were abundant 20 years ago but catches have since declined (GarcíaTellez 2002). Unfortunately, there are no fisheries records of E. itajara landings, in this or any region of the Yucatan, to determine the status of its populations or its fishery.

When systematic fisheries data are unavailable or limited, scientists of some countries have used the local ecological knowledge (LEK) of fishers for filling gaps in biological and fisheries information. In fact this LEK, which proved useful to complement scientific procedures (Johannes 1998, Huntington 2000, Silvano \& Begossi 2005, Gerhardinger et al. 2006), is defined as the "system" of understandings and the know-how arising through time from experiences and observations regarding the environment, behavioral attributes of animals, and ecological dynamics (Davis \& Wagner 2003).

This work aims to investigate the fishery status of E. itajara, based on both available fishery records and fishers LEK, from two traditional fishing ports (Dzilam de Bravo and Puerto Progreso) in the northern Yucatan Peninsula, Mexico. Conservation and management strategies for E. itajara in this region are needed because the southeastern Gulf of Mexico remains as a gap on the research issues of this grouper.

\section{MATERIALS AND METHODS}

Study Area: This study was conducted in two fishery ports on the northern Yucatan Peninsula, Mexico: Dzilam de Bravo and Puerto Progreso (Fig. 1). These are among the main fishery ports in the area. Dzilam de Bravo is a small town, located on the central
Yucatan coast $\left(21^{\circ} 26^{\prime} \mathrm{N}, 88^{\circ} 42^{\prime} \mathrm{W}\right)$ with a large $\left(10 \mathrm{~km}^{2}\right)$, shallow (average depth $0.6 \mathrm{~m}$ ) lagoon with bottom covered by seagrass beds (Halodule wrightii and Ruppia maritima) that run parallel to the coast bordered by mangroves (Rhizophora mangle). Both the lagoon and the Dzilam de Bravo town comprise the Dzilam State Reserve established in 1989 by the local

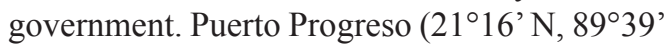
$\mathrm{W})$ is located west of Dzilam de Bravo and is the largest coastal town in the Yucatan. It also has a coastal lagoon (Estero Chelem, $14 \mathrm{Km}^{2}$ and $0.8 \mathrm{~m}$ in average depth).

Data collection: Visits to fisher cooperatives from Puerto Progreso and Dzilam de Bravo were conducted to compile fisheries landings records of E. itajara as much as possible. These cooperatives were selected from 16 sites, because they represent the most relevant landing sites in terms of capture volumes. Official fisheries logs were accessed and data on gutted weight and total length (TL, in $\mathrm{cm}$ ) were compiled. On occasions, only grouper weights were available from the fishers logs; thus, lengths were estimated using length-weight relationships reported in Bullock et al. (1992). Data from Puerto Progreso corresponded only to 1999 because this was the only data set available in the fisher cooperative. A relatively

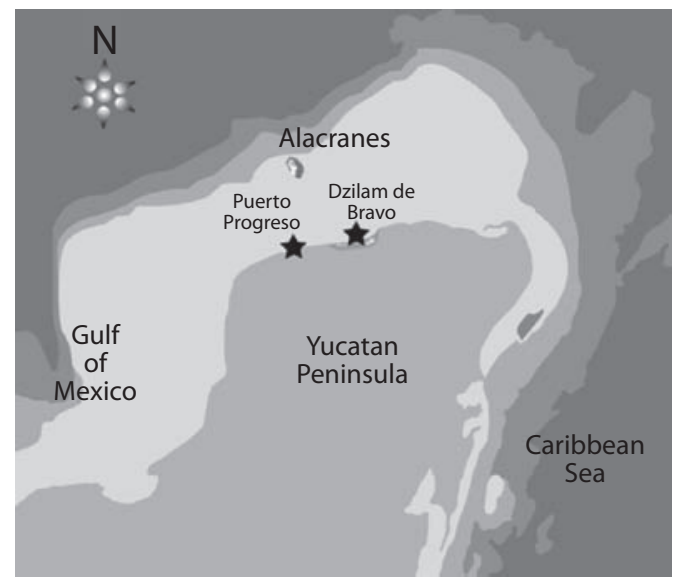

Fig. 1. Location of fishing ports (black stars) along the northern Yucatan Peninsula, Mexico. 
greater data set was obtained from Dzilam de Bravo corresponding to 2004, 2005 and 2006. In order to explore LEK, interviews were conducted with patriarch fishers who either used to or currently targeted E. itajara. At least 20 fishers were interviewed using semi-structured interviews in order to determine the 1) relative historic abundance of E. itajara, 2) fishing areas, 3) possible spawning sites and seasonality, 4) sex differentiation (morphological), 5) habitat preference (adults vs juveniles; this latter meant as those goliaths found in mangroves and exhibiting sized less than $50 \mathrm{~cm}$ in total length), 6) economic revenue from fishing (past vs today), and 7) most common fishing gear used. Out of these fishers, just 5 long-standing (veteran), skin diving fishers (more than 20 years of experience) provided almost complete answers, probably because they have a longer perspective on the fishery from the region. The selection of fishers was based on references of other fishers about spearfishing experience, and fishing in coastal lagoons. Fishers can recognize easily E. itajara from other groupers based on coloration patterns (presence of blotches, greenish coloration), thick lips, big mouth, and relatively big head.

Data analyses: One-way ANOVA was applied to determine significant differences in mean length among samples between years and localities (Dzilam de Bravo and Progreso). A Cochran test was used to test homogeneity of variances, and a Shapiro-Wilks test was performed to determine normality, with the level of significance set at 0.05 .

\section{RESULTS}

Goliath grouper landings for all years and sites combined was $2800 \mathrm{~kg}$ (879 kg for Puerto Progreso and $1921 \mathrm{~kg}$ for Dzilam de Bravo). Body size $(\mathrm{n}=43)$ ranged from 105 to $235 \mathrm{~cm}$ TL (mean $=142.4 \pm 29$ ), and gutted weight ranged from 18 to $180.5 \mathrm{~kg}$ (mean $=65 \pm 35.4$; Fig. 2). The body size range for groupers from
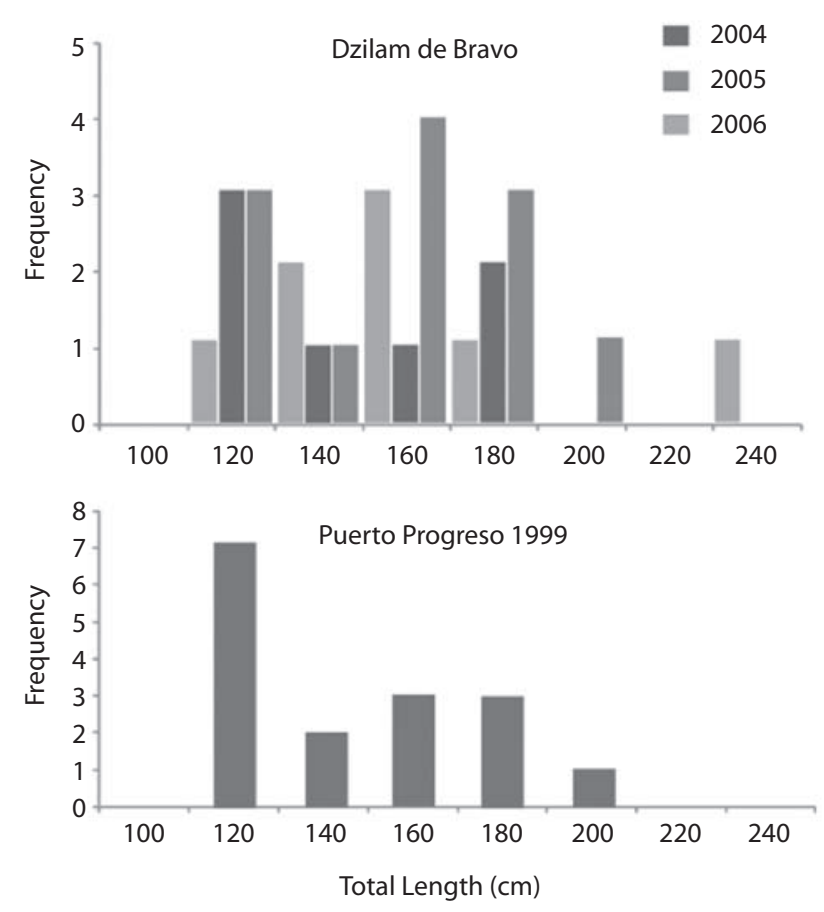

Fig. 2. Size distribution (cm, TL) of Epinephelus itajara from fishery landings of Dzilam de Bravo (upper, $\mathrm{n}=27$ ) and Puerto Progreso (lower, $\mathrm{n}=16$ ) from northern Yucatan Peninsula, Mexico. 
Dzilam de Bravo was 105-235 cm TL ( $\mathrm{n}=27$, mean $147 \pm 30 \mathrm{~cm}$ ) with a weight range of 18-181 kg (mean $71 \pm 37 \mathrm{~kg}$; Fig. 3), while the body size for Puerto Progreso was $105-185 \mathrm{~cm}$ $\mathrm{TL}(\mathrm{n}=16$, mean $=134.25 \pm 27 \mathrm{~cm})$ with a gutted weight range of $25-135 \mathrm{~kg}$ (mean $=55 \pm$ $31 \mathrm{~kg}$; Fig. 4). For Dzilam de Bravo, there was no significant difference in size $\left(\mathrm{F}_{2.24}=0.57\right.$, $\mathrm{p}=0.572)$ or weight $\left(\mathrm{F}_{2.24}=0.57, \mathrm{p}=0.574\right)$ among years. Size (cm, TL) and gutted weight from Dzilam de Bravo (all years, $\mathrm{n}=27$ ) and Puerto Progreso $(1999, \mathrm{n}=16)$ is shown in Fig. 4 ; there were significant differences found in size $\left(\mathrm{F}_{1.41}=2.16, \mathrm{p}=0.149\right)$ and weight $\left(\mathrm{F}_{.41}=\right.$ $2.01, \mathrm{p}=0.157)$ between localities. The lengthweight relationship for E. itajara for northern Yucatan Peninsula (including Puerto Progreso and Dzilam de Bravo) was given as $\mathrm{Y}=0.797 \mathrm{x}$ $+90.51\left(r^{2}=0.94\right.$; Fig. 5)

Based on local ecological knowledge from fishers, E. itajara is predominantly found in rocky (coral) bottoms, where fishers used to commonly catch individuals (up to $200 \mathrm{~kg}$ maximum) from February to October using mainly spearguns (Table 1). Veteran fishers (more than 25 years of experience) argue that E. itajara was very common (20 times more abundant) 35 years ago in similar areas where they are commonly taken, such as close to shore and coastal lagoons (juveniles). According to younger fishers (and also veterans), E. itajara is now rare to find during a fishing trip. Veteran fishers argue that commercial fishery began in 1973, when the lobster fishery was established;
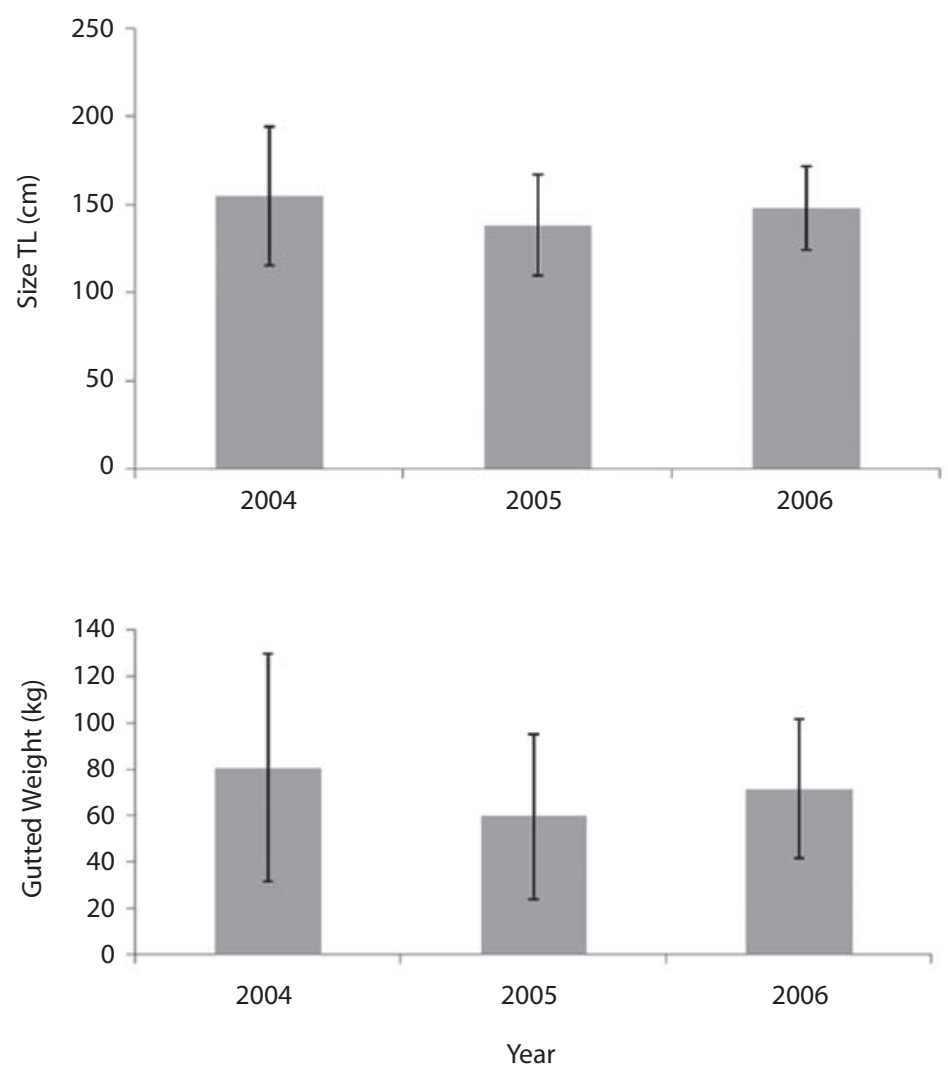

Fig. 3. Size (cm, TL) (upper) and Gutted Weight (lower) for Epinephelus itajara from landings (2004, 2005, 2006, $\mathrm{n}=27)$ of Dzilam de Bravo, Yucatan. 

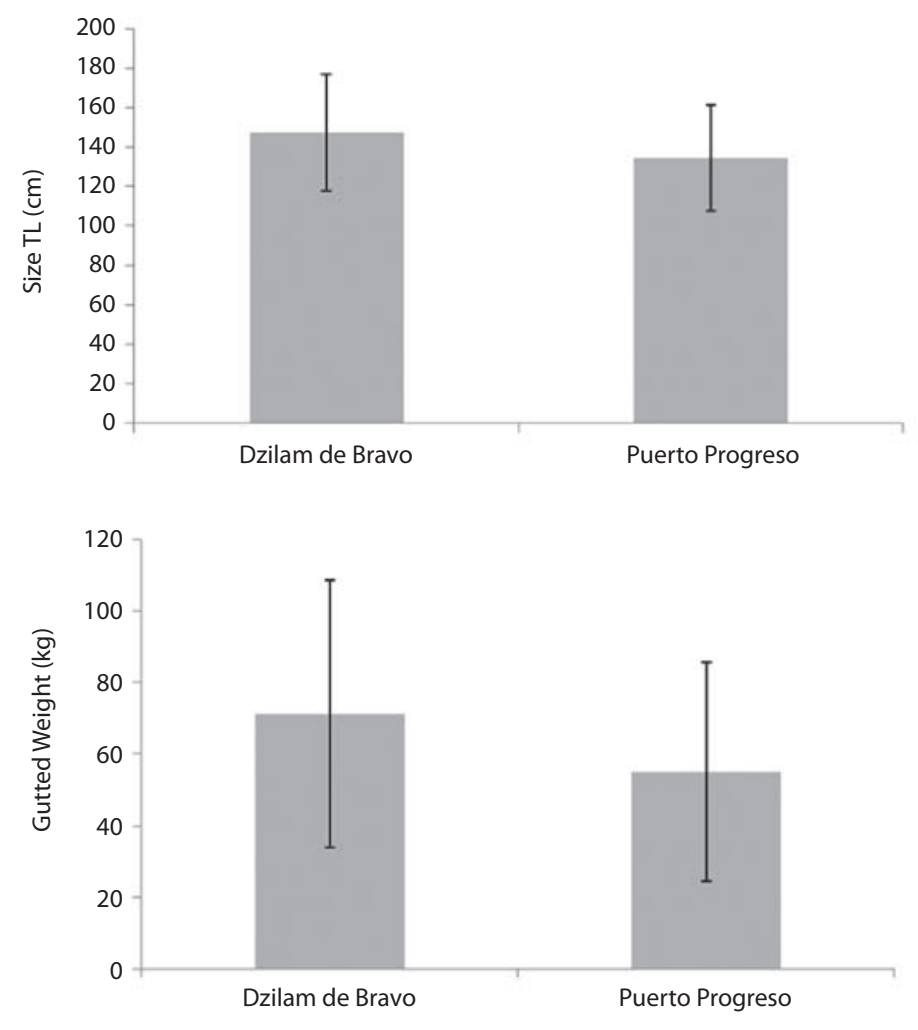

Localities

Fig. 4. Size (cm, TL) (upper) and Gutted Weight (lower) from Dzilam de Bravo (all years, $\mathrm{n}=27$ ) and Puerto Progreso $(1999, \mathrm{n}=16)$, Yucatan for Epinephelus itajara.

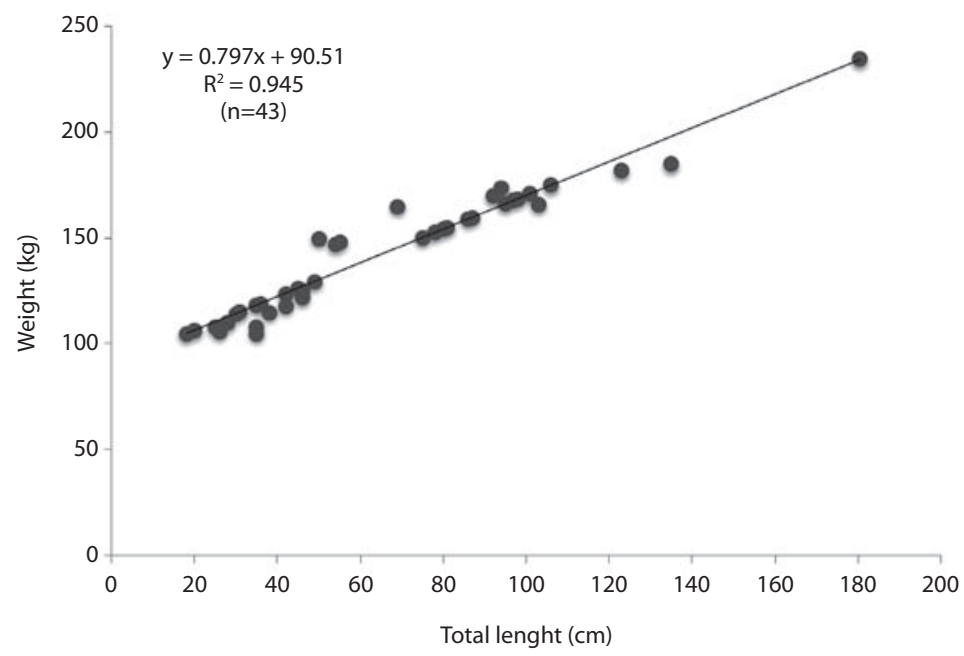

Fig. 5. Length-weight relationship for Epinephelus itajara from northern Yucatan Peninsula (including data of Puerto Progreso and Dzilam de Bravo, $\mathrm{n}=43$ ). 


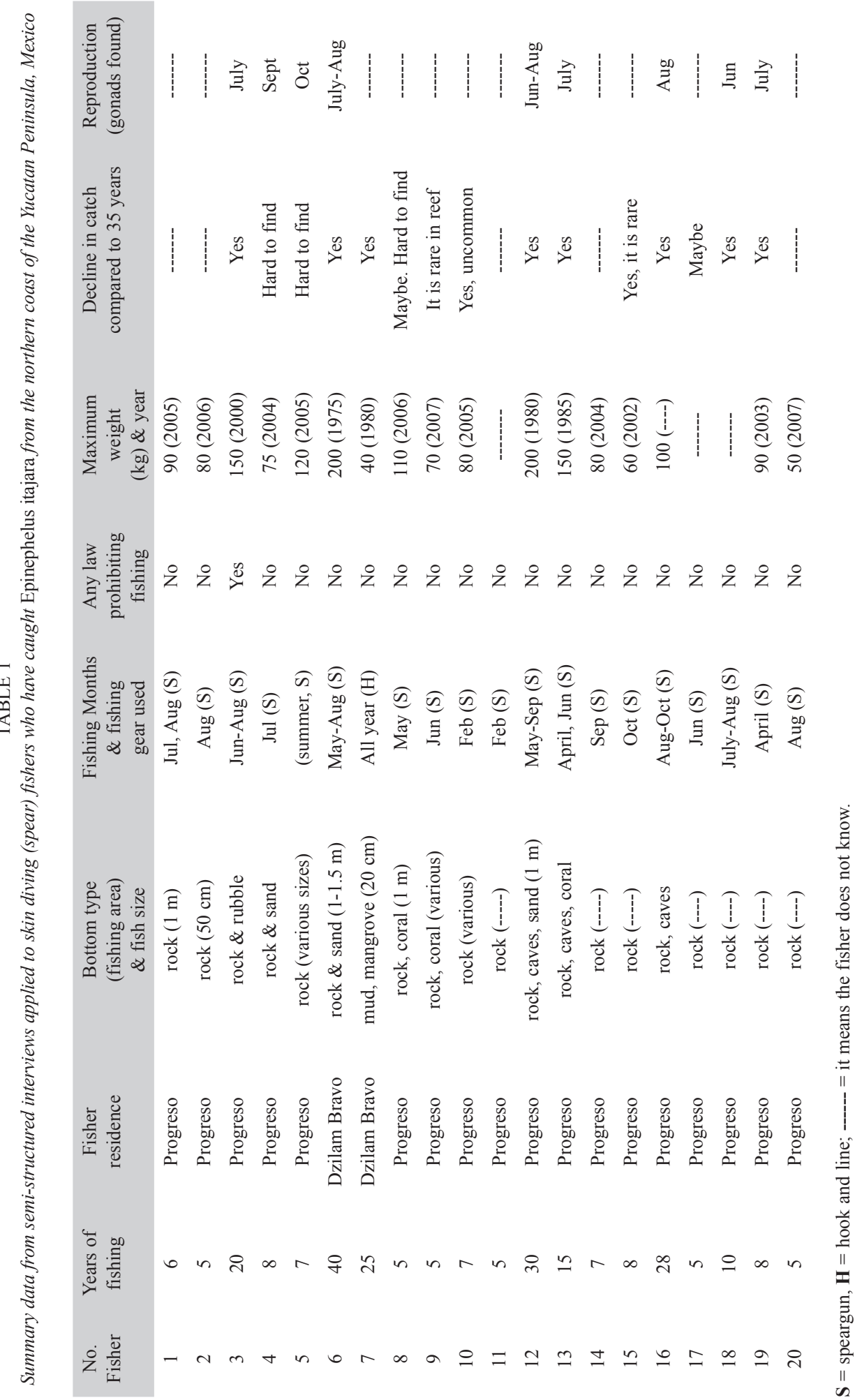


however, fishers have captured this grouper as second-hand opportunities after the lobster. Interviews reported historical catches of $E$. itajara of up to 100 individuals per month, depending on the lobster fishing season (July to February) since fishers primarily concentrate on lobster. When the lobster fishery was in closed season, fishers used to switch to catch E. itajara opportunistically.

According to fishers, the current level of the E. itajara fishery is unviable due to the relatively low stock abundance. Historic landings were primarily based on adults $(>150 \mathrm{~cm}$ TL), except when fishing occurred either close to shore or inside coastal lagoons when in these latter areas the catch was comprised mainly of juveniles ( $<100 \mathrm{~cm} \mathrm{TL}, 2-4 \mathrm{~kg}$ in weight). Some fishers have found that its reproductive period (based on the presence of gonads) comprises from July to August (Table 1).

\section{DISCUSSION}

The current status of E. itajara fisheries in the northern Yucatan Peninsula is unknown due to the scarcity of data. The present study revealed that four years of fisheries records taken by fishers logs from Dzilam de Bravo accounted only for 43 individuals (equivalent to almost 3 ton). Fishing effort assessment is not possible since official fishery records are infrequent and fishing effort (hours/diver) is not commonly recorded by authorities. However, low landing records suggest either a substantial decline in E. itajara abundances or underreporting, since this species is not regulated in the region. However, the former is also plausible due to the fishermen accounts assuring high levels of abundance more than 30 years.

According to fishers, the E. itajara fishery began parallel to the lobster fishery in the early 1970s. Fishers began catching lobsters (Panulirus argus) in relatively shallow rocky bottoms off Dzilam de Bravo, where they also found and spear-fished E. itajara. Moreover, many of the captured E. itajara had lobsters in their stomachs, which suggest that E. itajara were in those areas feeding on lobsters. Fishers identified July to September as the period for reproduction. In fact, in other areas of the Gulf of Mexico, such as the Florida Keys, peak catches correspond to July and August (Sadovy \& Eklund 1999).

The landings data for Dzilam de Bravo and Puerto Progreso reveals that catch recorded was comprised by adults (sexual maturity is reached by $100 \mathrm{~cm}$ TL [ 40 to $60 \mathrm{~kg}$ ] in the eastern Gulf of Mexico, Bullock et al. 1992). Catches from both ports were similar in size and weight (also among years), which indicates that fishers captured (using spearguns) similar sized individuals from the interspersed reefs on the platform off northern coast of Yucatan. Actually, the speargun is one of the gears used in the Yucatan for catching this and other grouper species, such as the black grouper, Mycteroperca bonaci.

The perspectives on the E. itajara fishery provided by fishers represent a very important aspect, and highlight the usefulness of LEK as contribution for scientific studies. Many of the fishers opinion about the current status of this grouper represent a clear evidence (supported by scientific studies elsewhere) on the decreasing status of E. itajara, its reproductive season, and habitat. Our procedure using LEK to filling gaps on important components of the conservation and management status of a fish adds on the evidence on how fishers information could be reliable for science (Mutuku-Mathooko 2005, Silvano \& Begossi 2005).

In the northern Yucatan, the viability of the E. itajara fishery has greatly diminished, and the species currently represents only an incidental catch from an opportunistic fishing. Scientifically, nothing is known about its biological characteristics from this region to develop conservation and management strategies. The government has not provided strong, decisive conservation initiatives for protecting this species. Due to its current and almost negligible fishery status, E. itajara is not detailed in the fishery legislation (SAGARPA 2004); but the fishery authority recognizes the need to conduct studies for establishing fishing regulations for various groupers (SAGARPA 2004). More attention is paid to other groupers, such 
as the red grouper, E. morio, since this latter still supports a substantial regional fishery (Giménez-Hurtado et al. 2005). In fact, relatively few species-level fisheries management exists in Mexico and most fish management in the Yucatan Peninsula is directed to this latter grouper (SAGARPA 2004).

The Norma Oficial Mexicana (Mexican Official Standard), known as NOM-065PESC-2006, was emitted by the federal government of Mexico (SAGARPA 2004) to regulate the fishery for groupers and associated species in the Gulf of Mexico and Mexican Caribbean, and recognizes E. itajara as a target species. However, the NOM-065-PESC-2006 does not detail any management measure (e.g. minimum size, etc.) and it still is a project that needs to be officially approved. There is a NOM established for the protection of native species from Mexico, categories at risk, and categories at risk for inclusion or exclusion in species listings (NOM-059-ECOL-2001), but it does not include E. itajara either.

A recent study covering a wide geographic scale used genetic and systematic approaches on E. itajara populations revealed that populations in the western Atlantic are separated into discrete populations, and populations in the Pacific and western Atlantic represent at least 2 species (Craig et al. 2008). Consequently, these findings suggest that populations/species now require separate and specific management and conservation strategies (Craig et al. 2008). This latter study implies that it is important to further study the E. itajara population, not only that off the Yucatan Peninsula coasts but in other areas of Mexico, such as the Pacific for finding better alternatives for conservation and management. For the northern Yucatan Peninsula, we recommend implementing a formal research program to determine the current distribution, abundance, and biological parameters (such as age and growth using dorsal spines) for both adults and juveniles of E. itajara.

Currently, there is substantial evidence that coastal lagoons with fringing mangroves are important nursery areas for this grouper (Frías-Torres 2006; Koenig et al. 2007). Consequently, it is viable that coastal lagoons in various locations (Celestún, Chelem, Dzilam de Bravo, Ría Lagartos) in northern Yucatan may function as key nursery areas for E. itaja$r a$. In fact, several of these coastal lagoons harbor juveniles of other grouper species (Renán et al. 2001). Finding and protecting spawning aggregations is of crucial importance for the persistence of fish populations since the reproduction is assured. As many other groupers, E. itajara aggregates to spawn (Colin 1994). According to one veteran fisher, an aggregation used to be common off Dzilam de Bravo during July comprising up to 40 individuals; however, there is not any scientific verification on the persistence of such aggregation. Likewise, other areas off the northern Yucatan Peninsula, such as Alacranes Reef, Bajos del Norte, Madagascar Reef, and Bajo Grandville, may represent potential locations for $E$. itajara aggregations. Consequently, it is necessary to conduct research in these areas for gaining more knowledge about the ecology of E. itajara in the region. In the meantime, it is urgent to halt its fishing and implement guidelines and regulations that follow international recommendations.

\section{ACKNOWLEDGMENTS}

We thank the fishermen from Dzilam de Bravo and Progreso for making fishery records accessible and sharing their perspectives on fishing history. Special thanks are given to the following veteran fishermen from Dzilam de Bravo: A. González "Bechá", M. Contreras "Maracas", R. Nadal "Cupi”, R. Ortíz "Topo", L. López "Lili.". Special thanks also for various fishers (mostly from Timucuy, Yucatan) who stay in Progreso but work in Alacranes Reef, from fisher cooperatives: Sisal, Del Golfo and Jurisdicción. 


\section{RESUMEN}

La cherna, Epinephelus itajara, un mero (Epinephelidae) corpulento $(\sim 2.5 \mathrm{~m} \mathrm{TL},>400 \mathrm{~kg})$ y amenazado, es altamente vulnerable a la sobrepesca. $\mathrm{Si}$ bien es protegido en varios países, en México su explotación no está regulada; situación que pone a su población en riesgo. Sus registros pesqueros son escasos, lo que impide determinar su condición pesquera. Este trabajo intentó ilustrar la pesquería en el norte de la Península de Yucatán usando procedimientos que involucraron analizar registros y entrevistar a pescadores veteranos (conocimiento ecológico tradicional) de dos sitios de desembarque: Dzilam de Bravo y Puerto Progreso. Se analizaron registros pesqueros históricos de dos cooperativas pesqueras para determinar la situación actual y ofrecer alternativas viables para conservación y manejo. Las capturas han disminuido drásticamente. El conocimiento local obtenido de los pescadores representa una fuente muy importante de información para ayudar a reconstruir la historia pesquera de esta especie. Se sugieren medidas de conservación que incorporen regulaciones nacionales e internacionales para especies de peces.

Palabras clave: pez arrecifal, mero Goliat, pesquería, conservación, Yucatán.

\section{REFERENCES}

Bullock, L.H., M.D. Murphy, M.F. Godcharles \& M.E. Mitchell. 1992. Age, growth, and reproduction of jewfish, Epinephelus itajara, in the eastern Gulf of Mexico. Fish. Bull. 90: 243-249.

Colin, P.L. 1994. Preliminary investigations of reproductive activity of the jewfish, Epinephelus itajara (Pisces: Serranidae). Proc. Gulf Carib. Fish. Inst. 43: 38-147.

Craig, M.T., R.T. Graham, R.A. Torres, J.R. Hyde, M.O. Freitas, B.P. Ferreira, M. Hostim-Silva, L.C. Gerhardinger, A.A. Bertoncini \& D.R. Robertson. 2008. How many species of goliath grouper are there? Cryptic genetic divergence in a threatened marine fish and the resurrection of a geopolitical species. Endang. Species Res. Doi: 10.3354/esr00117

Davis, A. \& J.R. Wagner. 2003. Who knows? On the importance of identifying "experts" when researching local ecological knowledge. Human Ecol. 31: 463-489.
Frías-Torres, S. 2006. Habitat use of juvenile goliath grouper Epinephelus itajara in the Florida Keys, USA. Endang. Species Res.1: 1-6.

García-Téllez, N. 2002. Situación actual de la cherna (Epinephelus itajara, Lichtenstein 1822) en la costa de Quintana Roo, Mexico, con énfasis en la Bahía de Chetumal. M.Sc. Thesis, ECOSUR.

Gerhardinger, L.C., R.C. Marenzi, A.B. Andrade, R.P. Medeiros \& M. Hostim-Silva. 2006. Local ecological knowledge on the Goliath Grouper Epinephelus itajara (Teleostei: Serranidae) in Southern Brazil. Neotropical Ichthyology 4: 441-450.

Giménez-Hurtado, R., E.R. Coyula-Pérez-Puelles, S.E. Lluch-Cotac, A.A. González-Yañez, V. MorenoGarcía \& R. Burgos-de-la-Rosa. 2005. Historical biomass, fishing mortality, and recruitment trends of the Campeche Bank red grouper (Epinephelus morio). Fish. Res. 71: 267-277.

Heemstra, P.C. \& J.E. Randall. 1993. FAO Species Catalogue. Groupers of the world (Family Serranidae, Subfamily Epinephelinae). An annotated and illustrated catalogue of the grouper, rockcod, hind, coral grouper and lyretail species known to date. FAO Fisheries Synopsis 16 (125).

Huntington, H.P. 2000. Using traditional ecological knowledge in science: methods and applications. Ecol. Appl. 10: 1270-1274.

Johannes, R.E. 1998. The case for data-less marine resource management: examples from tropical nearshore finfisheries. Trends Ecol. Evol. 13: 243-246.

Koenig, C.C., F.C. Coleman, A.M. Eklund, J. Schull \& J. Ueland. 2007. Mangroves as essential nursery habitat for goliath grouper (Epinephelus itajara). Bull. Mar. Sci. 80: 567-586.

Mutuku-Mathooko, J. 2005. Application of traditional ecological knowledge in the management and sustainability of fisheries in East Africa: a long-neglected strategy? Hydrobiologia 537: 1-6.

Porch, C.E. \& A.M. Eklund. 2004. Standardized visual counts of goliath grouper off south Florida and their possible use as indices of abundance. Gulf Mexico Sci. 2: 155-163. 
Renán, X., K. Cervera-Cervera \& T. Brulé. 2001. Probable nursery areas for juvenile groupers along the northern coast of the Yucatan Peninsula. Proc. Gulf Carib. Fish. Inst. 54: 496-505.

Sadovy, Y. \& A.M. Eklund. 1999. Synopsis of biological information on the Nassau grouper, Epinephelus striatus (Bloch 1792) and the jewfish, E. itajara (Lichtenstein 1822). NOAA Tech. Rep. NMFS 146.

SAGARPA (Secretaria de Agricultura, Ganadería, Desarrollo Rural, Pesca y Alimentación). 2004. Actualización de la Carta Nacional Pesquera y su anexo. Diario Oficial (México), lunes 15 de marzo de 2004, Segunda Sección: 1-112.

Silvano, R.A.M. \& A. Begossi. 2005. Local knowledge on a cosmopolitan fish ethnoecology of Pomatomus saltatrix (Pomatomidae) in Brazil and Australia. Fish. Res. 71: 43-59.

\section{INTERNET REFERENCE}

Chan, Tak-Chuen \& B. Padovani-Ferrera. 2006. Epinephelus itajara. In IUCN 2007. 2007 IUCN red list of threatened species. (Downloaded: October 15, 2007, www. iucnredlist.org). 